\title{
DEVELOPMENT OF WEB-BASED CHEMICAL LEARNING MEDIA IN COLOID SYSTEM TOPIC USING WORDPRESS
}

\author{
Elmaya Oktaviani ${ }^{1}$, Ucu Cahyana ${ }^{1}$ and Agung Purwanto ${ }^{1}$ \\ ${ }^{1}$ Department of Chemistry Education, Faculty of Mathematics and Natural Sciences, \\ Universitas Negeri Jakarta, Jl. Pemuda No. 10 Rawamangun, Pulo Gadung, Kota \\ Jakarta Timur, 13220, Indonesia \\ ‘E-mail: oktavianelmaya22@gmail.com
}

Received: 07 April 2020; Accepted: 25 June 2020; Published: 30 June 2020

\begin{abstract}
The study aimed to develop web-based learning media on colloidal system topic using wordpress CMS. It comes from challenges to make an attractive learning system for students. The research method ADDIE model developed by Dick and Carrey. The research instrument was questionaires. This learning media had been validated by media experts, material experts, chemistry educators and field trials. The result showed that the learning media is valid and feasible to be used in teaching and learning activities on system colloid lessons. It is proven based on the average score which is converted in to good and very good categories according to the ideal assessment criteria. While the result of small group trial showed the average scores of 19 and 19.4 for aspects of learning material and 35.5 and 38.1 for aspects of appearance and operation are both categorized as a good category.
\end{abstract}

Keywords: learning media, colloidal system, web, CMS wordpress

DOI : https://doi.org/10.15575/jtk.v5i1.7425

\section{INTRODUCTION}

Education is a fundamental aspect that must be held in everyone's life. Formal education includes the learning process in which there are teachers as educators and students as learners. Many problems are found in the world of education, one of them in the learning process that children are less motivated to develop the ability to think, since in the learning process children are only directed at the ability to memorize information. The child's brain is forced to remember and hoard various information without being asked to understand, remember and relate the information into their daily life (Suyanti \& Purba, 2017).
Teacher centered learning is one of the methods that does not increase students activities and it causes low learning outcomes (Kristanti et al., 2016). However, there are still many teachers who use this method in their learning activities. It is supported by the statement of Barron \& Darling-Hammond (2008) who noted that traditional approaches that focus on memorization or the application of simple procedures will not develop students' critical thinking skills and their autonomy.

It also supported by a research that was conducted in 2018 in a State Vocational School. The result showed that learning outcomes of chemistry students in colloidal system topic were not effective. Students 
were still look passive in some learning activities such as discussion. The implementation of the learning process that is less than the maximum can be seen from their learning outcomes which showed that $5 \%$ of students in class $\mathrm{XI}$ of Industrial Chemical Engineering had grades below the KKM (Minimum completeness criteria). Based on these data it can be said that learning outcomes of chemistry students are low (Eli \& Sari, 2018).

A previous study was conducted by researchers on 26 students consisting of 11 high school students and 15 vocational students in Jakarta and Bogor showed that in relation to the chemistry learning process, especially in colloidal topic, $60 \%$ of students said that the learning method was teachercentered. Meanwhile, there were $95 \%$ of students who interested in studying using electronic media. And about $60 \%$ of students believed that electronic media makes them better understand in learning colloidal systems. Moreover about 55\% of students did not want to use online learning. Based on these data it can be said that students will be more interested in if interactive media is used in learning activities and only a few teachers who had used technology as their learning resources.

A new learning model is expected to be developed since global era in the $21^{\text {st }}$ century the students will face complex global challenges. Identification of student competencies that need to be developed is very important to face the $21^{\text {st }}$ Century.

Furthermore, one way to overcome problems in teaching and learning process related to the complexity and uniqueness of learning, technology provides learning resources that facilitate problem solving in learning process. Thus, the use of technology is strived to provide greater opportunities for learning to occur within a person (Degeng, 2016).

There are many learning media based on technology. Among varieties of learning media, web is the right choice to use. Webbased learning media is a collection of pages on the internet that are designed in a planned and integrated way to be used in the interests of learning. It is expected that the educational communication interaction process between teachers and students can take place in an effective and efficient way. In addition, one of the reasons that web media is mostly used in learning activities is because the media can facilitate future development. Web media can also be run by many platforms (Widiyaningtyas \& Widiatmoko, 2014).

Web-based learning is a learning activity that utilizes website media that can be accessed through the internet network (Kurniawan et al., 2015). Based on previous studies conducted at several high schools and vocational schools in Jakarta and Bogor related to internet access owned by schools, it was found that schools in urban areas have fairly good internet access, it means that in the current digital era internet access is basic needs that need to be owned by school facilities.

Research that stated that there is increasing of learning outcomes using web media was done by Persada (2017) which showed that student learning outcomes are more effective using web-based teaching materials. Webbased learning media in this study used the Wordpress application, which is an open source application that is very popular to be used as a blog engine. Wordpress uses the PHP programming language (Hypertext Preprocessor) and the MySQL (My Structured Query Language) database both are open source software. Aside from being a blog, Wordpress also began to be used as a CMS (Content Management System) because of its ability to be modified and adapted to the needs of its users (Saluky, 2016). Websites that use the Wordpres CMS, users do not have to create a website from scratch (Rahman, 2018).

Colloidal system is one topic that can use web-based learning media. This material is widely used in daily life such as in industrial chemistry, for example in the manufacture of various products such as cosmetics, 
insecticides, cement, rubber, paper, plastics, textiles, inks, paints, ceramics, and so on. Processes such as whitening, removing odors, coloring, and purification involve adsorption on the surface of colloidal particles. Therefore, an understanding of the properties of colloids is very important in chemistry because the exploration of chemical materials is closely related to daily life and its various uses are needed by students in learning activities. However, in this material students are often less enthusiastic in learning and tend to feel bored (Eli \& Sari, 2018). This is because colloidal material is mostly theoretical and microscopic in nature, which students consider less important (Hayati et al., 2014). Students assume that they can memorize the material when they will face an exam. As a result, student learning activities become passive. Even though it is not that simple, the microscopic nature of colloidal topic can cause students' misconceptions (Hayati et al., 2014). Thus, the colloidal system material requires electronic learning media to increase student motivation in their learning activities. Previous research has been conducted using animation learning media about the colloidal system (Eli \& Sari, 2018). However, animated media which are generally in the form of flash have the disadvantage of only running on the Windows operating system or can only be used via a computer so students are unable to access via their tablet or smartphone (Fadillah, 2017).

Based on the background above, a research on the development of web-based learning media was carried out using ADDIE method by conducting research stages in the form analysis, design, develop, implement, and evaluate.

\section{RESEARCH METHOD}

The research method was ADDIE research and development developed by Dick and Carry (Branch, 2009). This research aimed to produce web-based learning media for colloidal system material. The stages of this research are as follows:

\subsection{Preliminary Research}

At this stage it was started by analyzing the needs of students and teachers. It was supposed to determine the needs and constraints of students and teachers in the learning activities of the colloidal system, also to determine the opinions of students and teachers about making learning media for learning activities so as to identify the needs of students to be further applied in making learning media.

\subsection{Media Development}

At this stage there were several activities, starting with the collection of materials and references which are components of the content that will be loaded into the learning web such as self-made animated videos and some from YouTube. The source of the book used comes from General Chemistry (Ebbing \& Gammon, 2016) and Basic Chemistry 2 (Sunarya, 2012). Then the material was developed and translated into the learning web. Until making this web-based media that uses Wordpress CMS with the ability to display HTML5 products. There is also several other supporting software, namely Microsoft PowerPoint 2016, Aiseesoft Total Video Converter, Corel Draw 5, and Photoshop X6. Web-based learning media developed have a design that can be explained in Figure 1. 


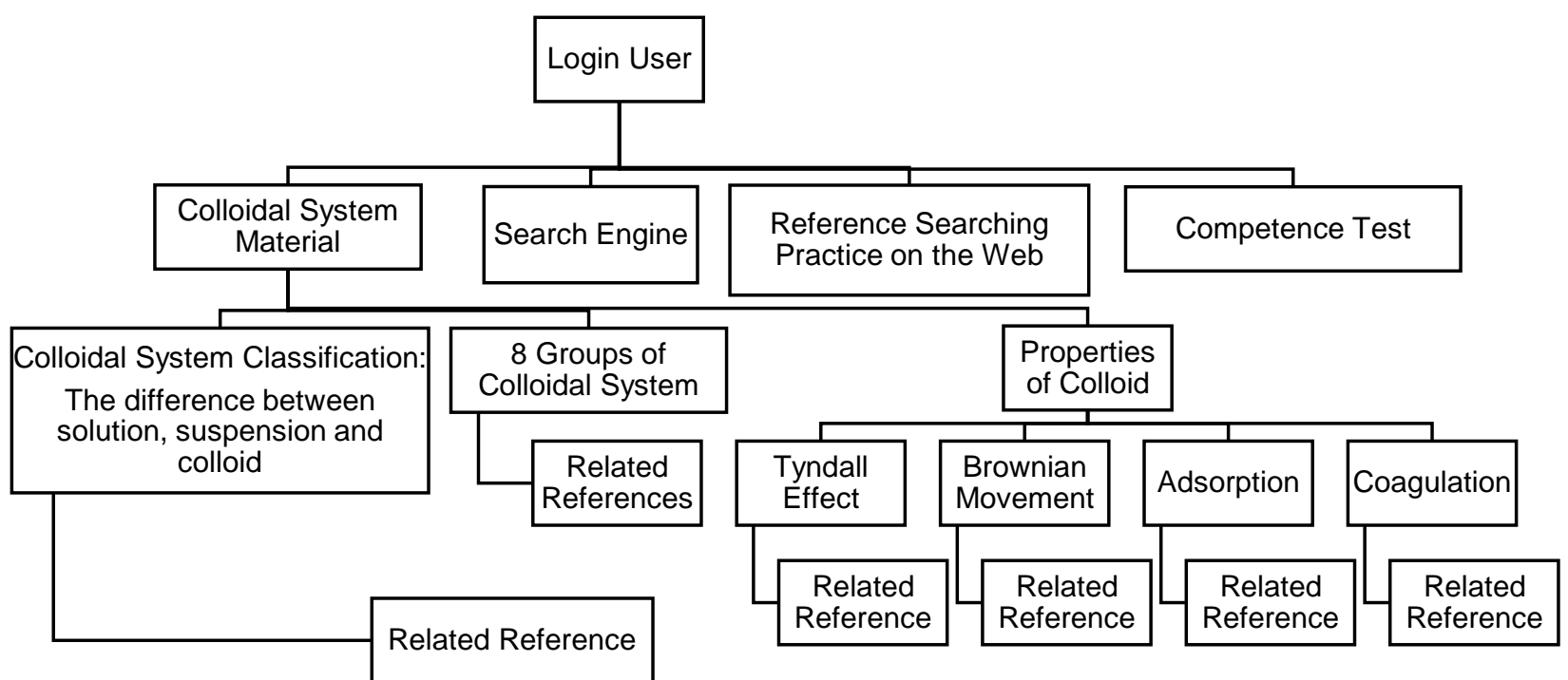

Figure 1. Storyboard for Making Colloidal Learning Media

The first page of the website is the home page. This page is the opening of the learning web, it contained a colloidal system concept that is packaged like a story so that it can make students were stimulated to be more interested in the learning web. The front page of the web can be seen in Figure 2.

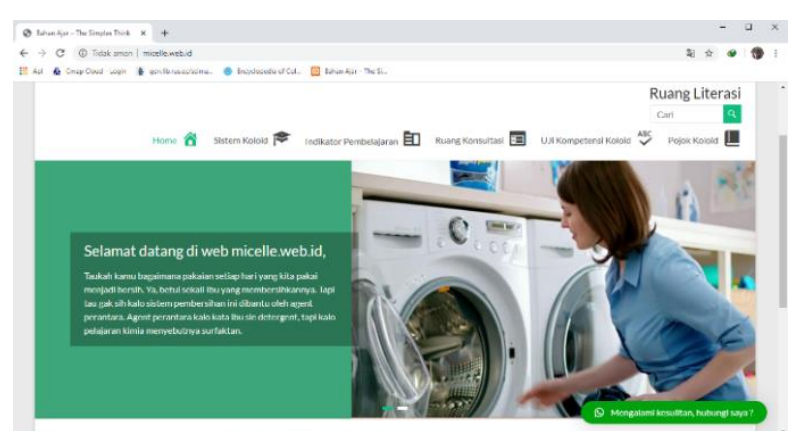

Figure 2. Front Page Display of the Web

The material of the solid system discussed in this learning web included the section on colloidal classification, the characteristic of colloids, the eight classes of colloidal systems, and the manufacture of colloids. Display page material contained on the learning web can be seen in Figure 3.

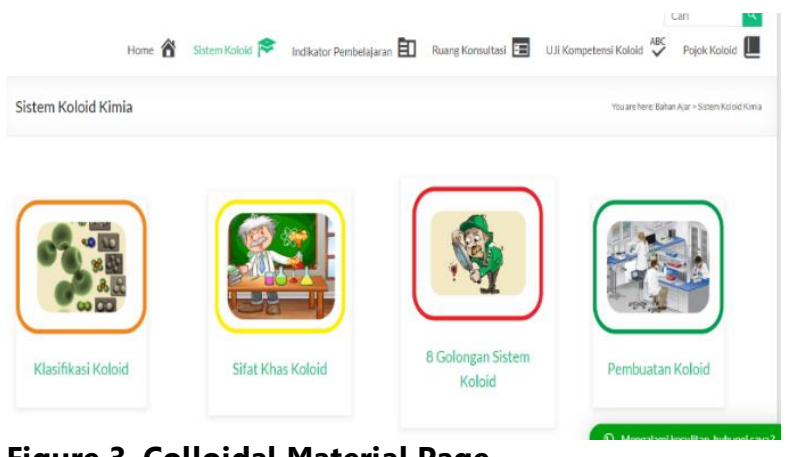

Figure 3. Colloidal Material Page

\subsection{Media Evaluation}

To determine the feasibility of the media, an assessment was carried out by material experts, media experts, students, and chemistry teachers. Media feasibility evaluation data covering aspects of learning, learning material content, visual and audio aspects, and software engineering aspects were obtained through material expert questionnaires, media expert questionnaires, student questionnaires and chemistry teacher questionnaires.

During the material expert test, a revision of the developed media was carried out. The revision process consisted of changing the name of the menu icon found on the learning web from "colloidal chemistry" to "colloidal system". Comparison of the appearance before and after the revision can be seen in Figure 4 and Figure 5. 


\section{Bahan Ajar}

The Simples Think

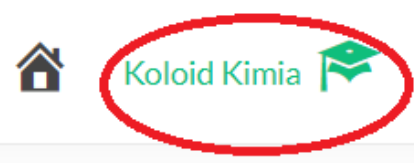

\section{Sistem Koloid Kimia}

\section{Figure 4. Icon Menu Before Revision}

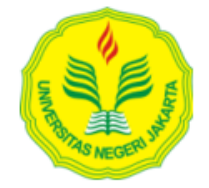

\section{Bahan Ajar}

The Simples Think

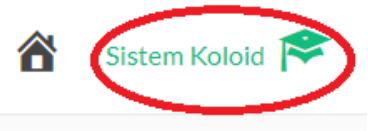

Sistem Koloid Kimia

Figure 5. Icon Menu After Revision

\subsection{Media Trial}

After learning media was assessed and validated by three material experts, three media experts and two chemistry educators, and have gone through a revision stage, the media were then tested on students. This trial consisted of a small group trial consisting of 15 students, then it was revised according to the opinions and input obtained then web learning through large group trial stages with the number of students 40 participants. The revised result of a large group trial resulted in a website-based learning media for colloidal material.

The instrument in this study was a needs analysis questionnaire. This questionnaire was in the form of a digital questionnaire (lime survey) aimed at several chemistry teachers and students of class XII high school and vocational high school in JABODETABEK. Then the material expert assessment sheet, the media expert, the chemistry educator, and the student assessment questionnaire were used. Evaluation of every aspect of the media developed in this study uses a Likert scale. Whereas the evaluation criteria are generally used for media quality (Widoyoko, 2013) can be seen in Table 1.

Table 1. Criteria for Evaluating Media Quality

\begin{tabular}{|c|c|c|}
\hline No. & Score Range (i) & Category \\
\hline 1 & $X>+1,8 . s b i \bar{X}_{i}$ & Very Good (SB) \\
\hline 2 & $\bar{X}_{i}+0,6 \cdot b i<X \leq+1,8 \cdot b i \bar{X}_{i}$ & Good (B) \\
\hline 3 & $\overline{\mathrm{X}}_{\mathrm{i}}-0,6 . \mathrm{sbi}<\mathrm{X} \leq+0,6 . \mathrm{sbi} \overline{\mathrm{X}}_{\mathrm{i}}$ & Enough $(\mathrm{C})$ \\
\hline 4 & $\bar{X}_{i}-1,8 . b i<X \leq-0,6 . b i \bar{X}_{i}$ & Less $(\mathrm{K})$ \\
\hline 5 & $X \leq-1,8 . s b i \bar{X}_{i}$ & Very Poor (SK) \\
\hline
\end{tabular}

Information:

$\bar{X}_{\mathrm{i}}$ (ideal average) $=$ (ideal maximum score + ideal minimum score) $\frac{1}{2}$

sbi (ideal standard = (ideal maximum score -

deviation) ideal minimum score) $\frac{1}{6}$

$\mathrm{X}=$ Empirical score

\section{RESULT AND DISCUSSION}

The results of this study produced a websitebased learning media for colloidal system material. At the stage of assessment by media experts, material experts, and educators obtained the results of the assessment analysis in Table 2. The assessment of media experts obtained an average score for the audio visual aspect of 45.7 with a good category, while for the software engineering aspect obtained an average score of 22 so that it is included in the category very good. 
Table 2. Results of the Assessment of Media Experts, Material Experts and Chemistry Educators

\begin{tabular}{|c|c|c|c|c|}
\hline \multicolumn{5}{|c|}{ A. Media Expert Rating } \\
\hline No. & Visual and Audio Aspects & $\begin{array}{l}\text { Expert } \\
1\end{array}$ & \begin{tabular}{|l|} 
Expert \\
2
\end{tabular} & $\begin{array}{l}\text { Expert } \\
3\end{array}$ \\
\hline 1 & Appropriate layout proportions (layout, text, images and animation) & 4 & 4 & 3 \\
\hline 2 & Appropriate color proportions & 5 & 5 & 3 \\
\hline 3 & Suitability of background selection & 4 & 5 & 4 \\
\hline 4 & Appropriate font selection & 5 & 5 & 3 \\
\hline 5 & Appropriate font size selection & 5 & 5 & 3 \\
\hline 6 & Attractive form of navigation buttons & 4 & 5 & 4 \\
\hline 7 & The consistency of the navigation button display & 4 & 4 & 4 \\
\hline 8 & Smooth animation movement & 4 & 5 & 4 \\
\hline 9 & The suitability of the animation with the material & 5 & 4 & 3 \\
\hline 10 & Suitability of supporting images with the material & 4 & 5 & 3 \\
\hline \multirow[t]{7}{*}{11} & Appropriate music selection accompaniment & 4 & 4 & 4 \\
\hline & Total & 48 & 51 & 38 \\
\hline & Average Score & \multicolumn{3}{|c|}{45.7} \\
\hline & Average Ideal Maximum Score & \multicolumn{3}{|c|}{55} \\
\hline & Average Ideal Minimum Score & \multicolumn{3}{|c|}{11} \\
\hline & Category & \multicolumn{3}{|c|}{ Well } \\
\hline & Software Engineering Aspects & $\begin{array}{l}\text { Expert } \\
1\end{array}$ & \begin{tabular}{|l|} 
Expert \\
2
\end{tabular} & $\begin{array}{l}\text { Expert } \\
3\end{array}$ \\
\hline 12 & Ease of operation of learning media & 4 & 5 & 4 \\
\hline 13 & Clarity of media usage guidelines & 4 & 5 & 2 \\
\hline 14 & Creativity and innovation in media & 5 & 4 & 5 \\
\hline 15 & Operating system compatibility with programs & 5 & 5 & 4 \\
\hline \multirow[t]{6}{*}{16} & $\begin{array}{l}\text { Media development opportunities for the development of science and } \\
\text { technology }\end{array}$ & 5 & 4 & 5 \\
\hline & Total & 23 & 23 & 20 \\
\hline & Average Score & \multicolumn{3}{|c|}{22} \\
\hline & Average Ideal Maximum Score & \multicolumn{3}{|c|}{25} \\
\hline & Average Ideal Minimum Score & \multicolumn{3}{|c|}{5} \\
\hline & Category & \multicolumn{3}{|c|}{ Very good } \\
\hline
\end{tabular}

\section{B. Material Expert Rating}

\begin{tabular}{|c|c|c|c|c|}
\hline No. & Learning Aspects & $\begin{array}{l}\text { Expert } \\
1\end{array}$ & $\begin{array}{l}\text { Expert } \\
2\end{array}$ & $\begin{array}{l}\text { Expert } \\
3\end{array}$ \\
\hline 1 & Learning indicators in accordance with $B C$ & 5 & 5 & 5 \\
\hline 2 & $\begin{array}{l}\text { Learning objectives are in accordance with indicators of competency } \\
\text { achievement }\end{array}$ & 5 & 5 & 5 \\
\hline 3 & $\begin{array}{l}\text { Learning material in accordance with indicators of competency } \\
\text { achievement }\end{array}$ & 5 & 5 & 5 \\
\hline 4 & Giving examples in accordance with the material & 5 & 5 & 5 \\
\hline & Total & 20 & 20 & 20 \\
\hline & Average Score & \multicolumn{3}{|c|}{20} \\
\hline & Average Ideal Maximum Score & \multicolumn{3}{|c|}{20} \\
\hline & Average Ideal Minimum Score & \multicolumn{3}{|c|}{4} \\
\hline & Category & \multicolumn{3}{|c|}{ Very good } \\
\hline
\end{tabular}




\begin{tabular}{|c|c|c|c|c|}
\hline No. & Content Aspect of Learning Material & $\begin{array}{l}\text { Expert } \\
1\end{array}$ & \begin{tabular}{l|l} 
Expert \\
2
\end{tabular} & $\begin{array}{l}\text { Expert } \\
3\end{array}$ \\
\hline 5 & The concept of matter is correct & 5 & 5 & 5 \\
\hline 6 & Neat material description & 4 & 5 & 5 \\
\hline 7 & $\begin{array}{l}\text { Writing the formulation of the questions in accordance with indicators } \\
\text { of competency achievement }\end{array}$ & 4 & 4 & 5 \\
\hline 8 & The material in learning media is interesting and motivating & 4 & 5 & 5 \\
\hline 9 & Correct use of language & 4 & 4 & 5 \\
\hline 10 & The sentence used does not lead to double interpretation & 4 & 4 & 4 \\
\hline & Total & 25 & 27 & 29 \\
\hline & Average Score & \multicolumn{3}{|c|}{27} \\
\hline & Average Ideal Maximum Score & \multicolumn{3}{|c|}{30} \\
\hline & Average Ideal Minimum Score & \multicolumn{3}{|c|}{6} \\
\hline & Category & \multicolumn{3}{|c|}{ Very good } \\
\hline
\end{tabular}

\section{Chemistry Teacher Evaluation of Material Aspects}

No. Learning Aspects

1 Learning indicators in accordance with $B C$

Learning objectives are in accordance with indicators of competency

2 achievement

Learning material in accordance with indicators of competency

3 achievement

$4 \quad$ Giving examples in accordance with the material

Total

Average Score

Average Ideal Maximum Score

Average Ideal Minimum Score

Category

Content Aspect of Learning Material

Educator 1 Educator 2

3

304

The concept of colloidal matter is correct

$6 \quad$ Explanation of coherent material

Writing the formulation of the questions in accordance with indicators

7 of competency achievement

8 The material in learning media is interesting and motivating

9 Correct use of language

10 The sentence used does not lead to double interpretation

Total

Average Score

Average Ideal Maximum Score

Average Ideal Minimum Score

Category

$4 \quad 3$

\begin{tabular}{l|l}
4 & 5 \\
\hline
\end{tabular}

\begin{tabular}{c|c}
4 & 5 \\
\hline 15 & 17
\end{tabular}

15

16

20

4

Well

Educator 1 1 Educator 2

\begin{tabular}{|c|c|}
\hline 3 & 5 \\
\hline 3 & 5 \\
\hline & \\
4 & 4 \\
\hline 5 & 5 \\
\hline 5 & 4 \\
\hline 5 & 5 \\
\hline $\mathbf{2 5}$ & $\mathbf{2 8}$ \\
\multicolumn{3}{|c|}{$\mathbf{2 6 . 5}$} \\
$\mathbf{3} \mathbf{3 0}$ \\
6ery good \\
\hline
\end{tabular}

\section{Evaluation of Chemical Educators in Media Aspects}

\section{No. Audio Visual Display Aspects}

1 Appropriate layout proportions (layout, text, images and animation)

2 Color proportion

3 Appropriate Selection of web background color

$4 \quad$ Appropriate font selection

5 Appropriate font size selection

6 Suitability The shape of the navigation buttons is interesting

Educator 1 Educator 2

\begin{tabular}{|l|l|}
\hline 3 & 4 \\
\hline 4 & 5 \\
\hline 5 & 5 \\
\hline 4 & 5 \\
\hline 4 & 4 \\
\hline 4 & 4 \\
\hline
\end{tabular}

This is an open access article under CC-BY-SA license (https://creativecommons.org/licenses/by-sa/4.0/) 


\begin{tabular}{|c|c|c|c|}
\hline No. & Audio Visual Display Aspects & Educator 1 & Educator 2 \\
\hline 7 & Appearance Display navigation buttons are consistent & 5 & 3 \\
\hline 8 & Suitability Movement of an attractive and smooth animation & 5 & 4 \\
\hline 9 & Suitability of Animation with material & 4 & 3 \\
\hline 10 & Compatibility of supporting images with material & 4 & 3 \\
\hline 11 & Appropriate selection of accompaniment music & 5 & 4 \\
\hline & Total & 47 & 44 \\
\hline & Average Score & \multicolumn{2}{|r|}{45.5} \\
\hline & Average Ideal Maximum Score & \multicolumn{2}{|r|}{55} \\
\hline & Average Ideal Minimum Score & \multicolumn{2}{|r|}{11} \\
\hline & Category & \multicolumn{2}{|c|}{ Well } \\
\hline & Software Engineering Aspects & Educator 1 & Educator 2 \\
\hline 12 & The operation of learning media is easy & 5 & 5 \\
\hline 13 & The instructions for using media are clear & 5 & 5 \\
\hline 14 & Creativity and innovation in media & 5 & 5 \\
\hline 15 & Operating system compatibility with programs & 3 & 5 \\
\hline \multirow[t]{6}{*}{16} & $\begin{array}{l}\text { Media development opportunities for the development of science and } \\
\text { technology }\end{array}$ & 3 & 5 \\
\hline & Total & 21 & 25 \\
\hline & Average Score & \multicolumn{2}{|r|}{23} \\
\hline & Average Ideal Maximum Score & \multicolumn{2}{|r|}{25} \\
\hline & Average Ideal Minimum Score & \multicolumn{2}{|r|}{5} \\
\hline & Category & \multicolumn{2}{|c|}{ Very good } \\
\hline
\end{tabular}

Material and learning objectives presented on the web according to experts supporting material will achieve the achievement indicators of student competency with a score of 5 for each expert. However, there are differences in assessment by the second chemistry educator who gives a score of 3 on the learning objectives, so it is necessary to review the learning objectives on the indicators of competency achievement by entering basic competencies from PERMENDIKBUD No. 37 in 2018 into the learning web. The learning indicators page display on the web can be seen in Figure 6 .

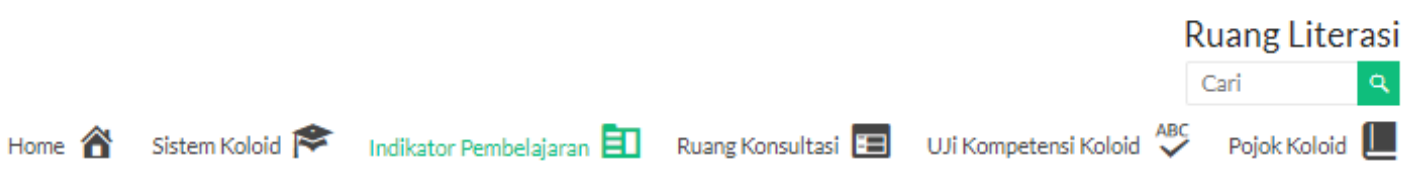

Indikator Pembelajaran

KOMPETENSI DASAR

3.14 Mengelompokkan berbagai tipe sistem koloid, dan menjelaskan kegunaan koloid dalam kehidupan berdasarkan sifat-sifatnya

4.14 Membuat makanan atau produk lan yang berupa koloid atau yang melibatkan prinsip koloid.

Figure 6. Indicators of Web Learning

Program evaluation of learning outcomes was carried out by conducting tests on students by giving test questions. According to educators, the writing of the formulation of 
questions posted on the web has a score of 4 so that both in achieving the student competency indicators this is in line with the results of the assessment by the material experts. One media expert gave a suggestion to provide a student discussion room on the learning web so that further a student consultation room was provided as shown in Figure 7, this consultation room was a two- way discussion room between teacher and student. In this page students will be able to give opinions and questions to the teacher, or comment on the opinions of the teacher and other students. So hopefully students can give their opinions freely. It causes the interaction between students and teachers not only limited to one learning environment.

\section{Ruang Konsultasi}

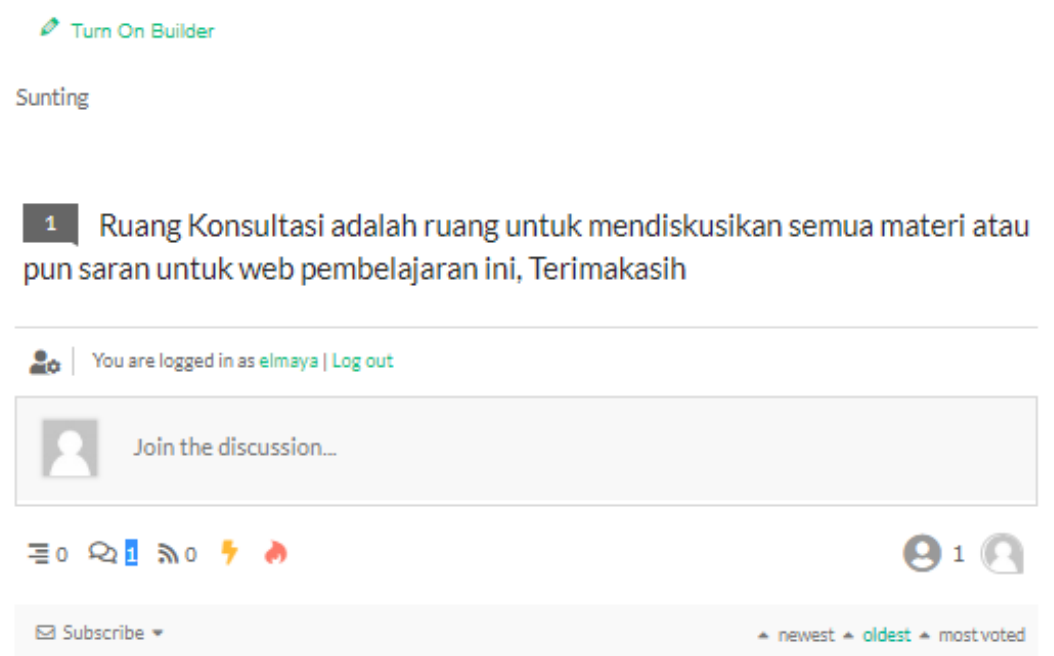

Figure 7. The Web Consultation Room Page

Based on Table 2 the analysis of the results of the expert material assessment on the learning aspects obtained an average of 20 for the assessment of the three material experts with very good categories and by 16 for the assessment of both chemistry educators with good categories. Based on these values, this learning media is expected to be able to present material that can improve student competence in colloidal chemical material.

Furthermore, to see the extent to which the effectiveness of this media was tested on students in small groups or large groups. The results of the trial evaluation analysis can be seen in Table 3.

Table 3. Analysis of the Results of the Small Group and Large Group Trial Evaluations

\begin{tabular}{|l|c|c|}
\hline Learning and Material Aspects & Small Group Trial & Large Group Trial \\
\hline Average score & 19 & 19.4 \\
\hline Average score max. ideal & 25 & 25 \\
\hline Average score min. ideal & 5 & 5 \\
\hline Category & Well & Well \\
\hline Display and Operational Aspects of Learning Media & Small Group Trial & Large Group Trial \\
\hline Average score & 35.5 & 38.1 \\
\hline Average score max. ideal & 50 & 50 \\
\hline Average score min. ideal & 10 & 10 \\
\hline Category & Well & Well \\
\hline
\end{tabular}


After an evaluation and revision of the learning media were assessed by experts and chemistry educators, a trial was conducted on the students. The trial was conducted with 15 students for small group trials and 40 students for large group trials. The results obtained in small and large group tests on aspects of learning and material produced an average score of 19 and 19.4 with both categories. Chemical material provided to students is applicable chemistry material. In the background of research on microscopic colloidal material properties can lead to student misconceptions (Hayati et al., 2014). It is because students only get the theory without seeing the difference visually. On the colloidal properties page on this web students are given a visual understanding that colloid is a system that is applied in everyday life. One example is the process of washing clothes. An example of a page containing an animation of washing clothes with soap can be seen in Figure 8.

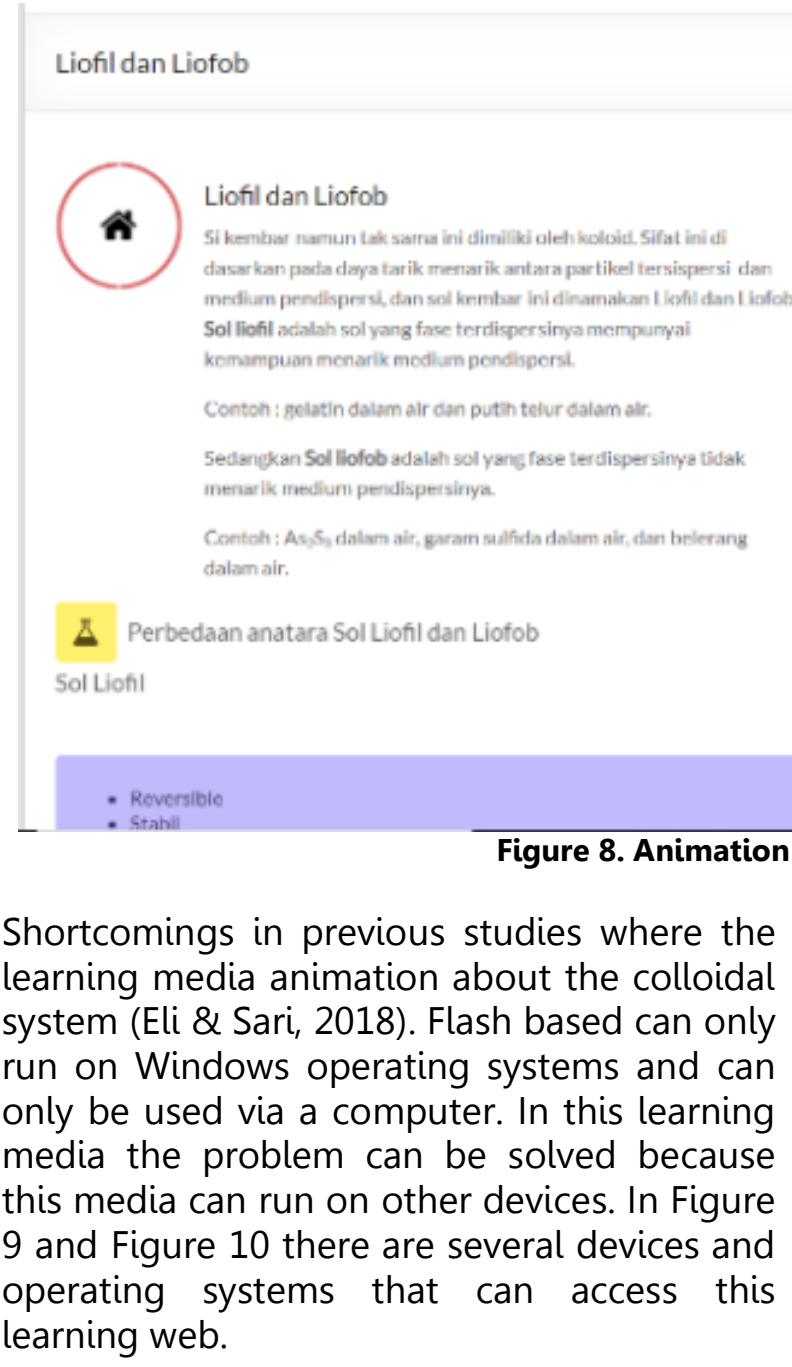

Shortcomings in previous studies where the learning media animation about the colloidal system (Eli \& Sari, 2018). Flash based can only run on Windows operating systems and can only be used via a computer. In this learning media the problem can be solved because this media can run on other devices. In Figure 9 and Figure 10 there are several devices and learning web.
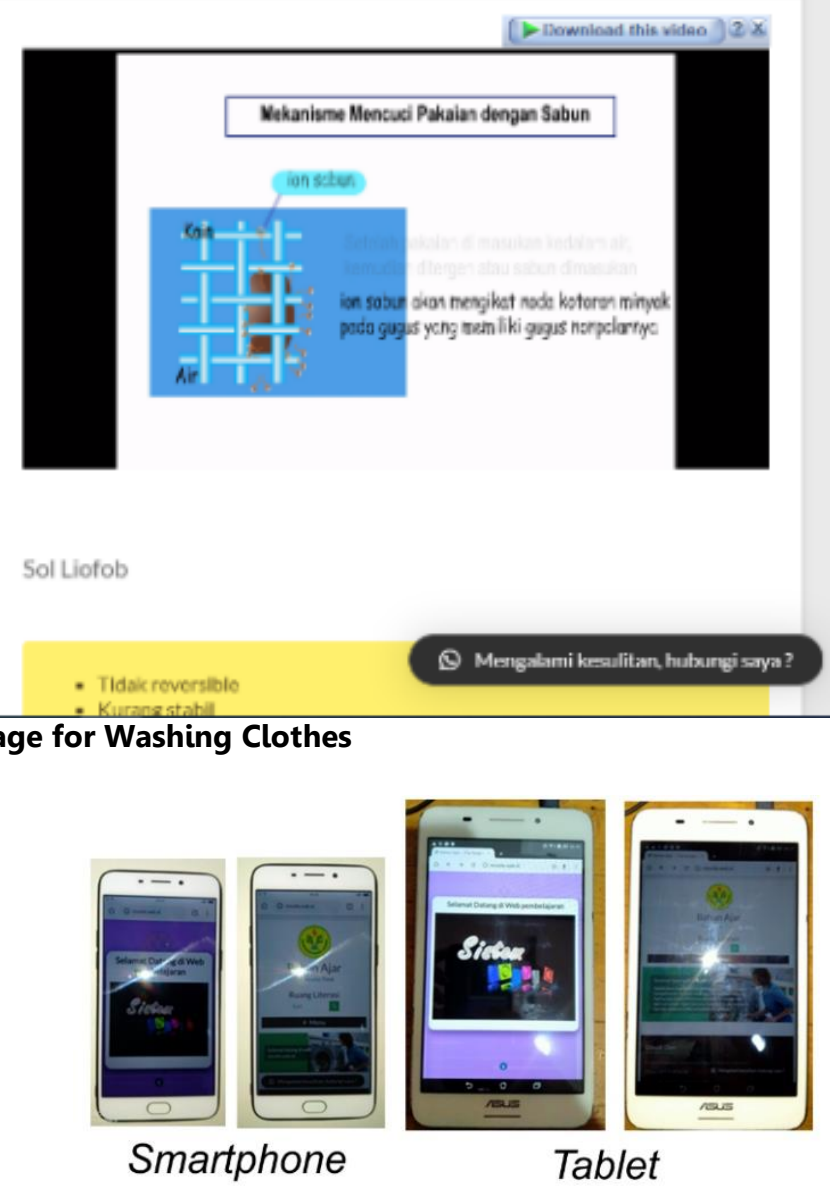

Figure 9. Device that Uses the Android Operating System 

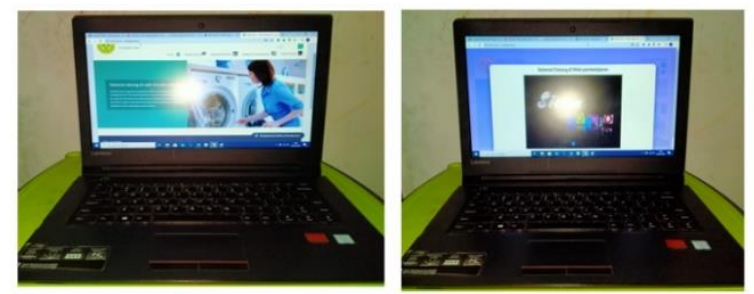

Laptop

Figure 10. Personal Computer Devices that Use the Windows Operating System

Web-based learning media that have been developed not only contains a variety of colloidal material, but also have the advantage that students can be actively involved in learning activities using the web directly through the device. This is due to the learning web is equipped with the WhatsApp plugin when students have accounts in their devices, students can communicate directly with the teacher through the WhatsApp program. Display WhatsApp plugins contained on the learning web can be seen in Figure 11.

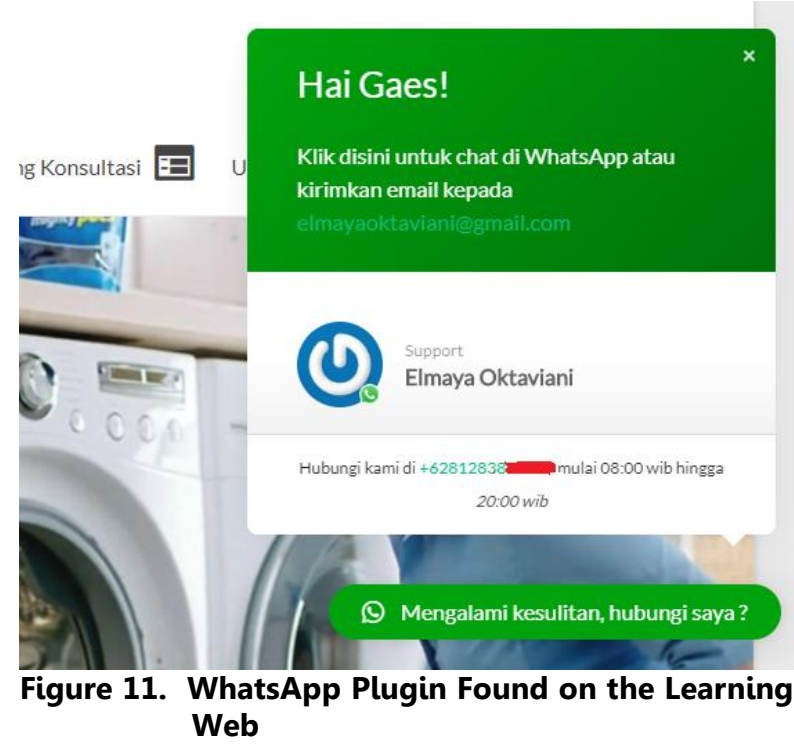

This learning web was also equipped with pages containing collections of bulletins and colloidal articles integrated into everyday life called chemistry corners. This page was created using the Wordpress flipbook plugin, so that it can make it easier for students to read it. The chemistry corner page display found on the learning web can be seen in Figure 12.

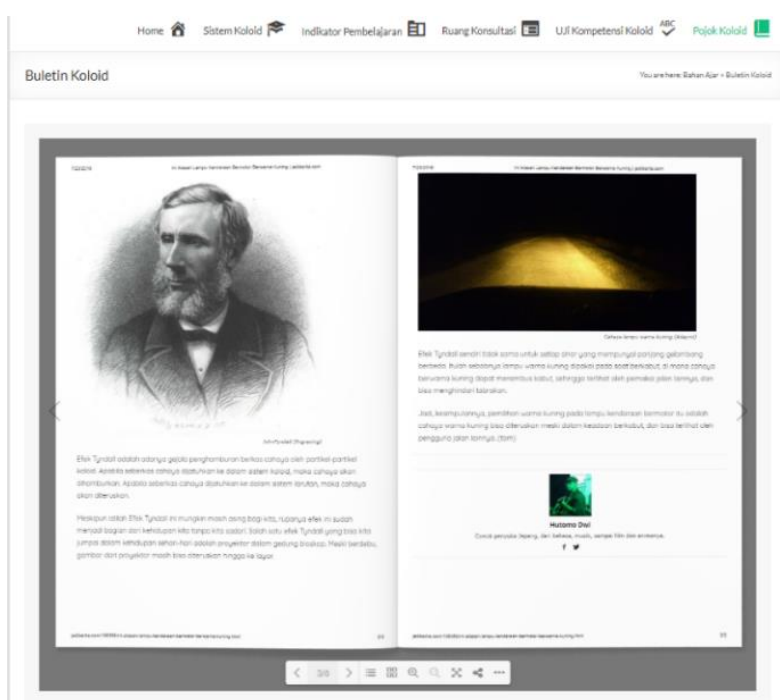

Figure 12. Chemistry Corner Page

Based on previous research, this web-based learning media has several advantages, namely its simple, yet elegant appearance. Have a complete variety of material as student learning materials independently. This can also be seen from the results of small trials and large trials that produce good categories. The integrated materials allow students to have interesting learning experiences because they are more interactive (Setyadi \& Qohar, 2017). This opinion is supported by Burrmann \& Moore (2013) which states that conventional learning has limited space and time in presenting a learning method. Meanwhile, web-based learning makes students do independent learning activities, anytime through the device or with their computer with internet access. Independent learning is very effective in making students to connect new concepts with prior knowledge.

\section{CONCLUSION}

Based on the analysis results and the trial data obtained, it can be concluded that the web-based learning media on the colloidal system topic that has been developed is valid and suitable to be used in teaching and learning activities. It can be proven based on the results of product validation and trials which on average obtain ideal evaluation criteria categorized as good and very good. 
This learning media is built with a load of applicative material such as the application of the water purification process by applying the principles of colloidal properties, so that it is hoped that in subsequent trials students can easily understand colloidal applications in daily life. However, this learning media is still limited in colloidal topic; therefore, it is expected that the next researchers can develop learning media in other chemical topics. 
Development of Web-Based Chemical Learning Media in Coloid System Topic Using Wordpress

\section{REFERENCES}

Barron, B., \& Darling-Hammond, L. (2008). Teaching for Meaningful Learning: A Review of Research on Inquiry-Based and Cooperative Learning. Book Excerpt. In George Lucas Educational Foundation. ERIC.

Branch, R. M. (2009). Instructional Design: the ADDIE Approach. USA: Springer science+Business Media.

Burrmann, N. J., \& Moore, J. W. (2013). Development of a Web-Based, Student-Centered Stereochemistry Tutorial. Journal of Chemical Education, 90(12), 1622-1625.

Degeng, M. D. K. (2016). Pengaruh Learning Control dalam Pembelajaran Menggunakan Media Web terhadap Hasil Belajar Pengetahuan Prosedural. Jurnal Pendidikan dan Pembelajaran, 23(02), 90-95.

Ebbing, D., \& Gammon, S. D. (2016). General Chemistry. Cengage Learning.

Eli, R. N., \& Sari, S. (2018). Pembelajaran Sistem Koloid Melalui Media Animasi untuk Meningkatkan Aktivitas dan Hasil Belajar Siswa. Jurnal Tadris Kimiya, 3(2), 135-144.

Fadillah, A. (2017). Pengembangan Bahan Ajar Kimia Berbasis Web dengan HTML 5 pada Materi Pokok Bahasan Bentuk Molekul di SMA-IT Thariq Bin Ziyad. Tesis, FMIPA: Universitas Negeri Jakarta.

Hayati, D. K., Sutrisno, S., \& Lukman, A. (2014). Pengembangan Kerangka Kerja TPACK pada Materi Koloid untuk Meningkatkan Aktivitas Pembelajaran dalam Mencapai HOTS Siswa. EduSains: Jurnal Pendidikan Matematika Dan Ilmu Pengetahuan Alam, 3(1). https://doi.org/10.22437/jmpmipa.v3i 1.1766
Kristanti, Y., Subiki, S., \& Handayani, R. (2016). Model Pembelajaran Berbasis Proyek (Project Based Learning Model) pada Pembelajaran Fisika Disma. Jurnal Pembelajaran Fisika Universitas Jember, 5(2), 122-128.

Kurniawan, D., Riyana, C., \& Rusman. (2015). Pembelajaran Berbasis Teknologi Informasi dan Komunikasi. Jakarta: Rajawali Pers.

Persada, A. R. (2017). Peningkatan Hasil Belajar Matematika Melalui Pengembangan Bahan Ajar Berbasis Website. Eduma: Mathematics Education Learning and Teaching, 6(1), 62. https://doi.org/10.24235/eduma.v6i1.1 661

Rahman, S. (2018). Buku Sakti SEO Wordpress dan Joomla. Jakarta: Elex Media Komputindo.

Saluky, S. (2016). Pengembangan Bahan Ajar Matematika Berbasis Web dengan Menggunakan Wordpress. Eduma: Mathematics Education Learning and Teaching, 5(1), 80-90.

Setyadi, D., \& Qohar, A. (2017). Pengembangan Media Pembelajaran Matematika Berbasis Web pada Materi Barisan dan Deret. Kreano, Jurnal Matematika Kreatif-Inovatif, 8(1), 1-7.

Sunarya, Y. (2012). Kimia Dasar 2 (1st ed.). Bandung: Yrama Widya.

Suyanti, R. D., \& Purba, D. M. (2017). The Implementation of Discovery Learning Model Based on Lesson Study to Increase Student's Achievement in Colloid. Aip Conference Proceedings 1823, 020090. https://doi.org/10.1063/1.4978163 
Widiyaningtyas, T., \& Widiatmoko, A. (2014). Media Pembelajaran Berbasis Web pada Mata Pelajaran Kimia. Jurnal TEKNO, 21(01), 47-51.

Widoyoko, E. P. (2013). Evaluasi Program Pembelajaran Panduan Praktis bagi Pendidik dan Calon Pendidik (5th ed.). Yogyakarta: Pustaka Pelajar. 